\title{
Geochemical Study of Soils, Road Dust and Stream Sediments around Ijebu-Ode, Southwestern, Nigeria Olatunji Akinade $\mathbf{S}^{*}$ and Olisa $\mathbf{O}$ \\ Department of Geology, University of Ibadan, Ibadan, Nigeria
}

\begin{abstract}
The study was aimed at an assessment of the heavy metal distribution in soils, road dust and stream sediments of the city of ljebu-Ode in order to evaluate the effects of increased urbanization on the quality of the environmental media89 samples comprising 30 topsoil, 54 road dust and 5 stream sediments samples were collected. The samples were air-dried, disaggregated and sieved for the fine fractions $(<75 \mu \mathrm{m})$. Portion of the samples were soaked in deionized water for forty-eight hours in the laboratory and the resulting solution was measured for Electrical Conductivity (EC), $\mathrm{pH}$ and Total Dissolved Solids (TDS) using standard digital probes. $0.5 \mathrm{~g}$ of the fine fractions of each sample was subsequently digested using hoy aqua-regia and analyzed for elemental concentration using Inductively Coupled Plasma Optical Emission Spectrometry (ICP-OES). The sieve analysis showed that the soils in the area are silty-sands in nature. The measured $\mathrm{pH}$ ranges from (6.1 to 7.6); (6.1-7.6) and (7.0-7.2) for Soil, road dust and stream sediments respectively. The EC ranges from $(1-131 \mu \mathrm{S} / \mathrm{cm}) ;(6-27 \mu \mathrm{S} / \mathrm{cm})$ and $(24-387 \mu \mathrm{S} / \mathrm{cm})$ in soil, stream sediments and in road dust while the TDS ranges from (0.4-89 $\mathrm{mg} / \mathrm{l}) ;(3-16 \mathrm{mg} / \mathrm{l})$ and $(13-248 \mathrm{mg} / \mathrm{l})$ in soils, stream sediments and in road dust. The elemental analysis revealed the following trends for selected metals in soils, sediments and road dusts respectively $\mathrm{Cu}(9.0-23.0,12.0-1170$ and 7.0-37.0); $\mathrm{Pb}$ (11.0-1056, 14.0-679.0 and 16.0-127.0); $\mathrm{Zn}$ (15.0-348.0, 86.0-730.0 and 36.0-412.0); $\mathrm{Ni}(6.0-12,5.0-21.0$ and 4.0-15.0); V(35.0-121.0, 34.0-113.0 and 29.0-135.0), $\mathrm{Cr}$ (25.094.0, 34.0-213.0 and 36.0-177.0) and As (2.0-11.0, 2.0-22.0 and Below detection limit, bdl-19.0). Further geochemical evaluation of the metals using metal ratio, geo-accumulation index revealed significant concentration of $\mathrm{Cu}, \mathrm{Pb}, \mathrm{Zn}, \mathrm{Ni}$, As and $\mathrm{Cr}$ in the environmental media from within the city Centre and along major roads in the city. Extreme metal loads associated with areas of huge vehicular activities, waste dumps and zones with agricultural activities.
\end{abstract}

Keywords: Urbanization; Environmental media; Metal loads

\section{Introduction}

Heavy metals are part of the natural system where they are rarely toxic owing to the nature of their occurrence as they are locked within the crystal structures of naturally occurring minerals where they are not usually bioavailable. However, they could become available through pedogenic and volcanic activities in addition to agricultural, energy production, mining and smelting activities, waste incineration and from automobile exhaust $[1,2]$. Heavy metals are not biodegradable and may exist within geological media for a long period of time depending on several factors and they may end up polluting water supplies and impacting the food chain thereby causing harm to living organisms. Though some members of the group such as $\mathrm{Cu}, \mathrm{Zn}$ and $\mathrm{Mn}$ are required for plant growth [3] hence the presence of heavy metals in earth materials does not necessarily always an indication of contamination.

Due to increase in awareness that health risk in urban areas could be related to environmental contamination and as a result of increase in anthropogenic influences on earth materials, geochemical mapping of urban environmental media has found increased applications to issues concerning environment and health [4-10].

Cities in developing countries like Nigeria have developed without requisite planning leading to poorly developed housing units and layouts with non-availability of appropriate infrastructure and amenities that could service them. The impact of this unplanned urbanization on the quality of environmental media in these cities is largely unknown as they have not been studied. This investigation was designed to partly meet this challenge by providing detailed geochemical evaluation of environmental media (soils, road dusts and sediments) in the city of Ijebu-Ode in southwestern Nigeria.

The city of Ijebu-Ode is defined by Longitude $3^{\circ} 5^{\prime} 15^{\prime \prime}$ and $4^{\circ} 00^{\prime} 00^{\prime \prime}$ and Latitude $6^{\circ} 47^{\prime} 15^{\prime \prime}$ and $6^{\circ} 51^{\prime} 45^{\prime \prime}$ (Figure 1). The city is located about $80 \mathrm{~km}$ to Lagos.

Geologically, the study area lies within a transition zone between the Precambrian Basement Complex of Southwestern Nigeria and the Cretaceous sediments of the Abeokuta Group in the eastern part of the Dahomey basin. The Basement Complex is dominant in the northeastern part and typically exposed rock units are Biotite Granite Gneiss; Biotite hornblende gneiss and Migmatite gneiss with varying degrees of fracturing while the southern region of the study area is composed of sedimentary sequences which lie unconformable on the basement complex rocks (Figure 2). According Jones and Hockey [11], Omatsola and Adegoke [12] and Agagu [13], the Dahomey Basin is filled with Cretaceous-Jurassic sediments which were derived from different sources (clastic, lacustrine, and marine) due to series of marine transgression and regressions.

\section{Materials and Methods}

89 samples comprising of 54 road dust samples, 5 stream sediments and 30 soil samples were collected. Road dust samples were collected at selected locations from major and minor roads in the city. Stream sediments samples were collected from the river flowing through the

*Corresponding author: Olatunji Akinade S, Department of Geology, University of Ibadan, Ibadan, Nigeria, Tel: 2348055475865; E-mail: akinadeshadrach@yahoo.com

Received May 05, 2014; Accepted June 17, 2014; Published June 20, 2014

Citation: Akinade SO, Olisa O (2014) Geochemical Study of Soils, Road Dust and Stream Sediments around ljebu-Ode, Southwestern, Nigeria. J Environ Anal Toxicol 4: 229. doi: 10.4172/2161-0525.1000229

Copyright: (c) 2014 Akinade SO, et al. This is an open-access article distributed under the terms of the Creative Commons Attribution License, which permits unrestricted use, distribution, and reproduction in any medium, provided the original author and source are credited. 
Citation: Akinade SO, Olisa O (2014) Geochemical Study of Soils, Road Dust and Stream Sediments around ljebu-Ode, Southwestern, Nigeria. J Environ Anal Toxicol 4: 229. doi: 10.4172/2161-0525.1000229

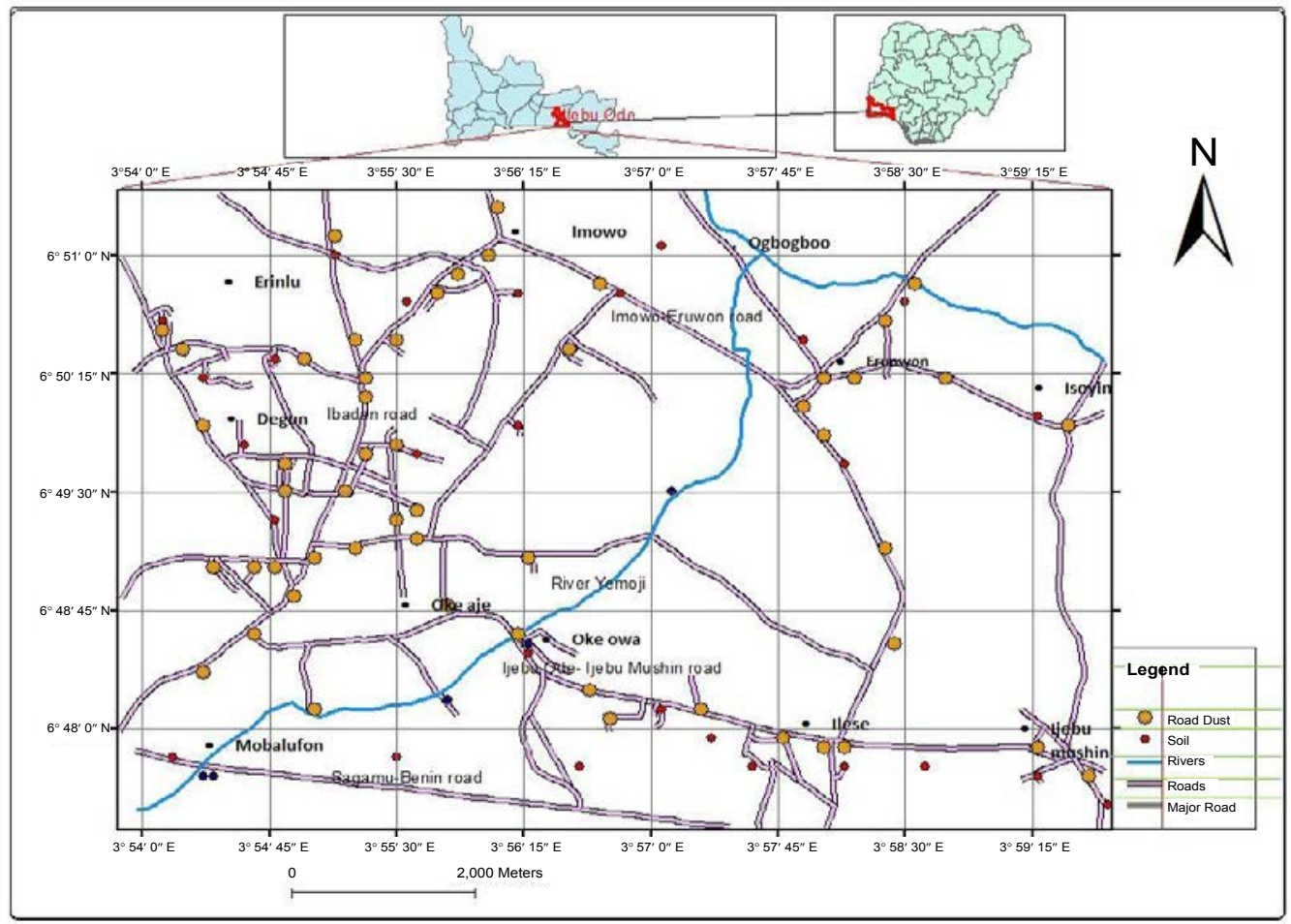

Figure 1: Location map of the study area

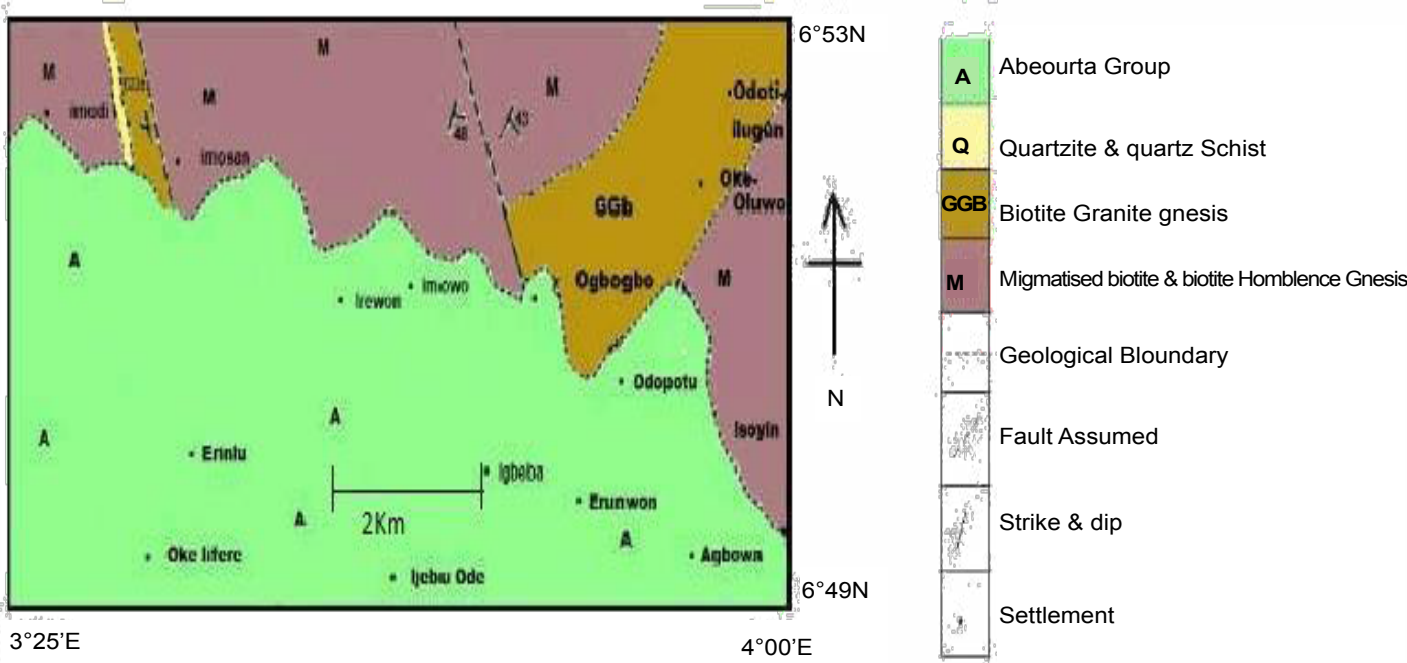

Figure 2: Geological map of the study area (Osinowo \& Olayinka, 2012).

city at points of accessibility. Samples were taken from the middle of the rivers. Composite samples of the stream sediments were made from homogenizing 5 samples obtained from the vicinity of the selected sampling points. Sub-soil samples were collected on gridding system. Depth of sampling varies from $20 \mathrm{~cm}$ to $30 \mathrm{~cm}$; this was to avoid sampling of topsoil. The Soil samples were collected from the center of each grid as well as four other points $200 \mathrm{~m}$ away from the selected central point and composited. All sample locations were appropriately identified using the GPS.
Samples were air-dried and were sieved to determine their granulometric distribution. Physico-chemical parameters $(\mathrm{pH}$, Total Dissolved Solids (TDS) and Electrical Conductivity (EC)) were determined by measuring $25 \mathrm{~g}$ of the sieved samples into clean beakers and $100 \mathrm{ml}$ of de-ionized water was added, the mixture were thoroughly stirred and allowed to stay undisturbed for 48 hours. The $\mathrm{pH}, \mathrm{EC}$ and TDS of the solutions were then measured using a Hach Eco Digital meter. $0.5 \mathrm{~g}$ of the sieved portion of each sample was subsequently digested by aqua-regia and analysed for elemental constituents using 
Citation: Akinade SO, Olisa O (2014) Geochemical Study of Soils, Road Dust and Stream Sediments around ljebu-Ode, Southwestern, Nigeria. J Environ Anal Toxicol 4: 229. doi: 10.4172/2161-0525.1000229

Page 3 of 10

the Inductively Coupled Plasma Optical Emission Spectrometry (ICP-OES). The obtained results were then used for the generation of geochemical maps using ArcGIS. Further statistical and geochemical evaluation of the results were also undertaken to determine elemental associations and quality of the environmental media.

\section{Results and Discussion}

\section{Granulometric distribution}

The granulometric study revealed that sand fractions constitute $47 \%$; silt fractions $58 \%$ while the clay fractions $5 \%$. The soils were mainly ferralitic in nature with a reddish tone and based on the results of the granulometric analysis can be described as silty sands. These types of soils have high infiltration capacity and may be very permeable to run-off and precipitations.

\section{Physico chemical parameters}

The $\mathrm{pH}$ ranges from 6.7-7.2 for soils, 6.1-7.6 for road dusts and 7.0-
7.2 for the sediments. The electrical conductivity (EC) of the samples ranges from $1-131 \mu \mathrm{S} / \mathrm{cm}$ for soil, $24-389 \mu \mathrm{S} / \mathrm{cm}$ for road dusts and 6-27 $\mu \mathrm{S} / \mathrm{cm}$ for sediments. The TDS values ranges from $0.4-89 \mathrm{mg} / \mathrm{l}$ for soil, 13-248 $\mathrm{mg} / \mathrm{l}$ for road dusts and between 3-16 mg/l for the sediments.

\section{Metal distribution}

The results for the geochemical analysis revealed varying concentration for different elements in the sampled media employed in the study (Table 1).

Geochemical maps (Figures 3-9) were prepared for selected elements $(\mathrm{Pb}, \mathrm{Cu}, \mathrm{Zn}, \mathrm{As}, \mathrm{Ni} \mathrm{Th}$, and $\mathrm{Ba})$ by plotting the elemental results as spatial distribution maps. The geochemical maps reveal different patterns of elemental distribution influenced to a great extent by both urbanization and geology. Areas with high population density recorded elevated concentration $\mathrm{Cu}, \mathrm{Pb}, \mathrm{Zn}$ and $\mathrm{As}$ in both the soil samples and road dust samples. This is believed to have resulted from intense level of anthropogenic activities coupled with huge traffic

\begin{tabular}{|c|c|c|c|c|c|c|c|c|}
\hline \multirow[t]{2}{*}{ Element } & \multirow{2}{*}{$\begin{array}{c}\text { Soils } \\
\text { Range }\end{array}$} & \multirow[b]{2}{*}{ Mean \pm Std.Dev } & \multicolumn{2}{|c|}{ Road Dust } & \multicolumn{2}{|c|}{ Stream } & \multirow[b]{2}{*}{+} & \multirow[b]{2}{*}{++} \\
\hline & & & Range & Mean \pm Std.Dev & Range & Mean \pm Std.D & & \\
\hline $\mathrm{Cu}$ & 23-Sep & $15.23 \pm 3.56$ & $12-117$ & $49.46 \pm 24.3$ & Jul-37 & $27.8 \pm 12.28$ & 21 & 27 \\
\hline $\mathrm{Pb}$ & $11-1056$ & $61.97 \pm 188.6$ & $14-679$ & $110.65 \pm 124.3$ & 16- 127 & $69.0 \pm 39.95$ & 35 & 58 \\
\hline $\mathrm{Zn}$ & $15-348$ & $68.7 \pm 71.9$ & $86-730$ & $274.7 \pm 149.8$ & $36-412$ & $264.4 \pm 162.7$ & 139 & 156 \\
\hline $\mathbf{N i}$ & 12-Jun & $8.97 \pm 1.7$ & 21-May & $11.24 \pm 3.6$ & 15-Apr & $9.20 \pm 3.96$ & 8 & 10 \\
\hline Co & 13-Mar & $5.74 \pm 2.1$ & $25-F e b$ & $5.75 \pm 3.3$ & 7-Feb & $4.8 \pm 1.92$ & 5 & 4 \\
\hline Mn & $238-1503$ & $483.4 \pm 604.1$ & $175-1508$ & $416.35 \pm 181.5$ & $78-370$ & $261.6 \pm 112.8$ & 440 & 280 \\
\hline As & $11-\mathrm{Feb}$ & $3.267 \pm 2.05$ & 22-Feb & $4.67 \pm 3.7$ & Bdl- 19 & $11 \pm 8.09$ & 2 & 3 \\
\hline Th & 18-Apr & $9.17 \pm 3.71$ & 30-Apr & $6.91 \pm 3.9$ & 19-Jul & $10.8 \pm 4.82$ & 7 & 8 \\
\hline $\mathrm{Sr}$ & $6-25$ & $11.5 \pm 4.66$ & Jun-71 & $18.94 \pm 10.2$ & 20-Apr & $15.0 \pm 7.0$ & 17 & 12 \\
\hline V & $35-121$ & $78.37 \pm 23.51$ & $34-113$ & $57.7 \pm 18.4$ & $29-135$ & $80.0 \pm 40$ & 68 & 72 \\
\hline $\mathrm{Cr}$ & $25-94$ & $50.2 \pm 18.21$ & $34-213$ & $95.41 \pm 41.7$ & $36-177$ & $111.4 \pm 50.7$ & 89 & 103 \\
\hline $\mathrm{Ba}$ & Dec-53 & $25.90 \pm 10.58$ & $25-195$ & $60.944 \pm 28.11$ & $13-60$ & $44.0 \pm 17.98$ & 56 & 50 \\
\hline
\end{tabular}

\pm Background concentration for soils and road dust \pm \pm Background concentration for stream sediments Bdl-Below Detection Limit

Table 1: Summary of element concentration of ljebu-ode and environ.

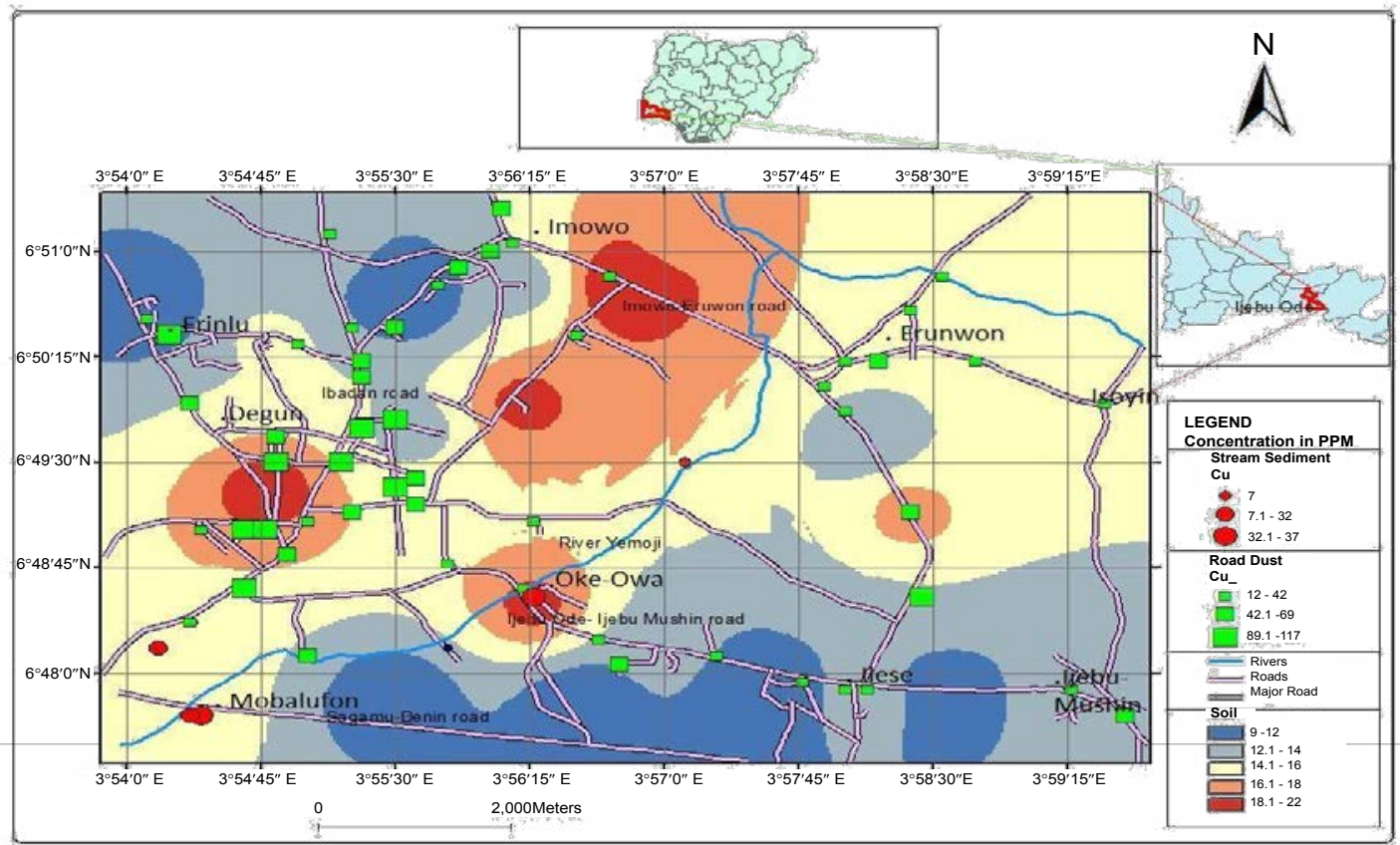

Figure 3: Spatial distribution of $\mathrm{Cu}$ in ljebu-Ode 
Citation: Akinade SO, Olisa O (2014) Geochemical Study of Soils, Road Dust and Stream Sediments around ljebu-Ode, Southwestern, Nigeria. J Environ Anal Toxicol 4: 229. doi: 10.4172/2161-0525.1000229

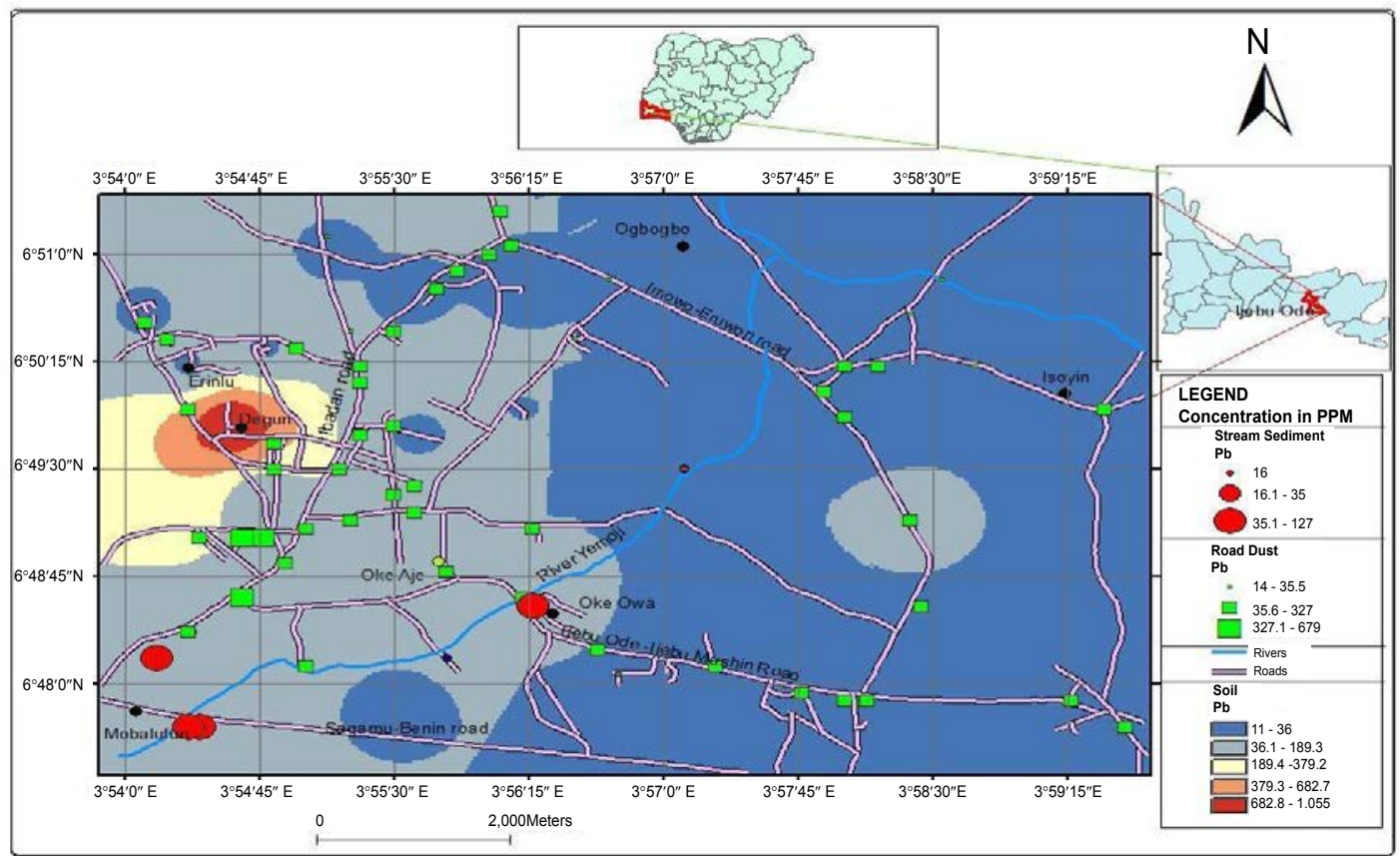

Figure 4: Spatial distribution of $\mathrm{Pb}$ in ljebu- Ode.

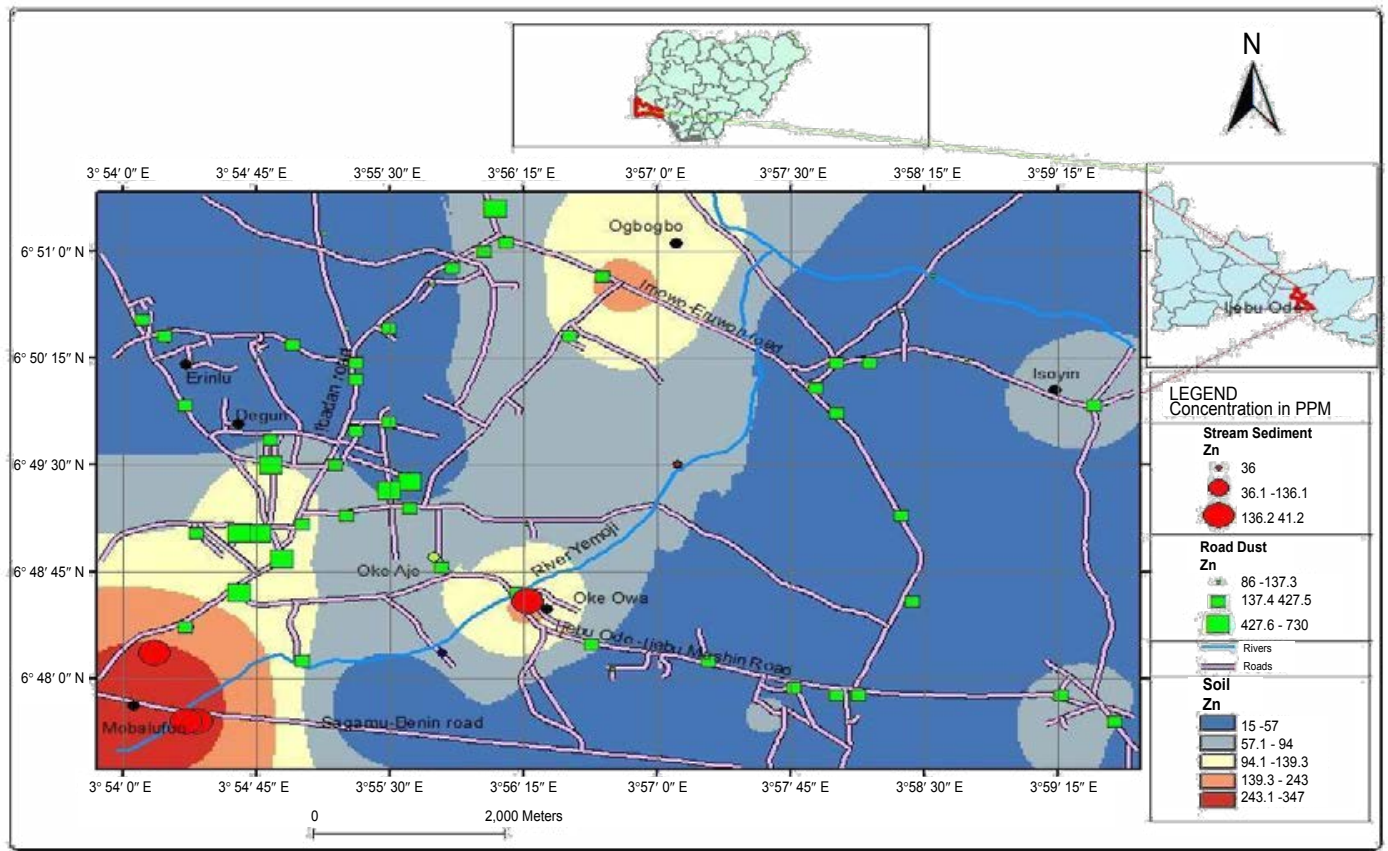

Figure 5: Spatial distribution of $\mathrm{Zn}$ in of ljebu-Ode.

density (Figures 3-6).

$\mathrm{Th}, \mathrm{Ni}$ and Ba were found to be elevated in areas where there are no population or traffic effects (Figures 7-9). These have been sourced into the soils of the area by weathering effects of the underlying rock units.

\section{Metal association}

The results were subjected to statistical analysis to determine the relationships between the various elements in the environmental media in order to assess the sources from which these elements have been contributed into the media and their state of occurrence.

\section{Correlation analysis}

High correlation coefficients between pair of elements or groups of element may be indicative of similar geochemical processes, factors and reactions which may have influenced metal distribution while marked differences in element correlations may indicate dissimilar source 
Citation: Akinade SO, Olisa O (2014) Geochemical Study of Soils, Road Dust and Stream Sediments around ljebu-Ode, Southwestern, Nigeria. J Environ Anal Toxicol 4: 229. doi: 10.4172/2161-0525.1000229

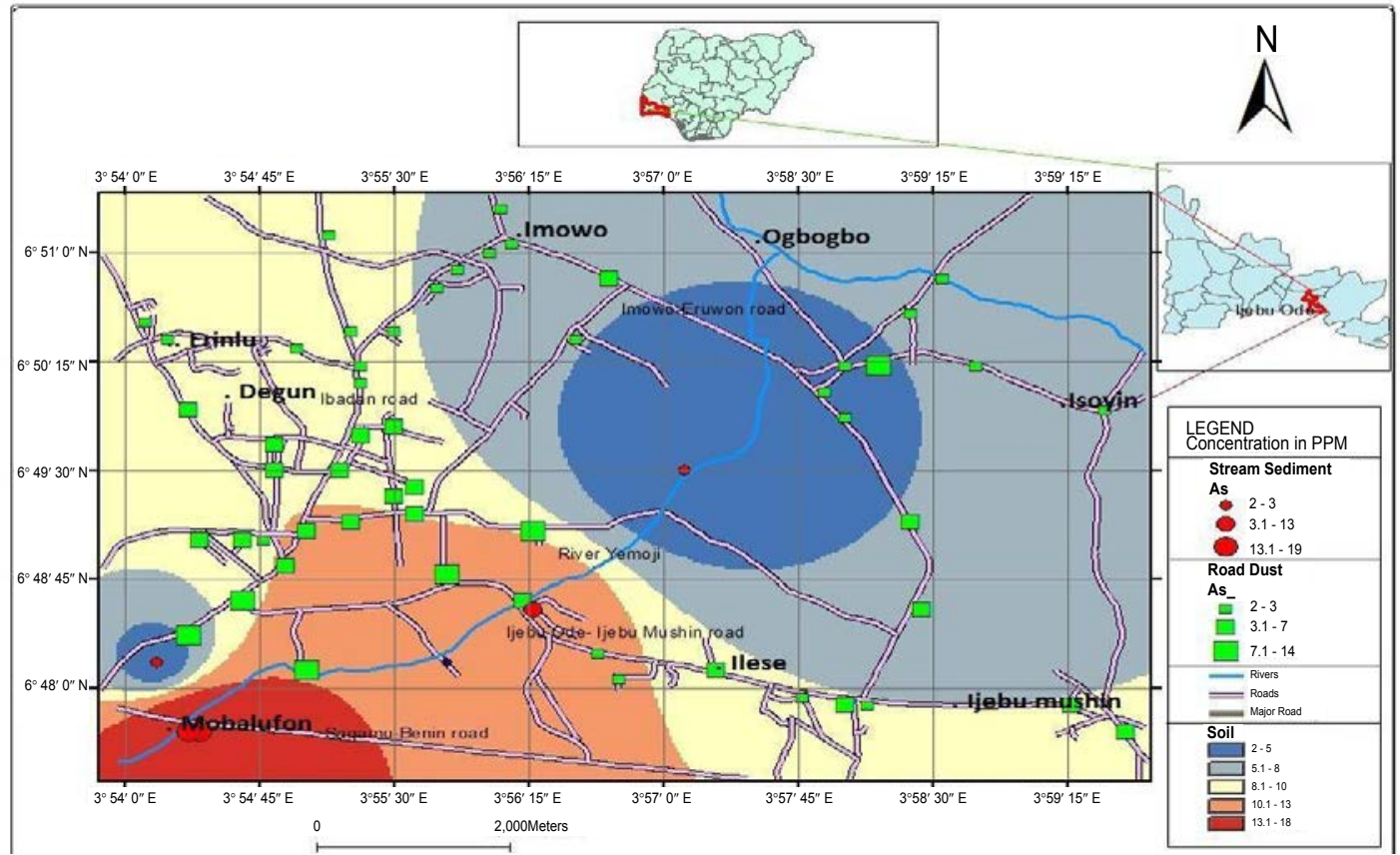

Figure 6: Spatial distribution of As in ljebu-Ode.

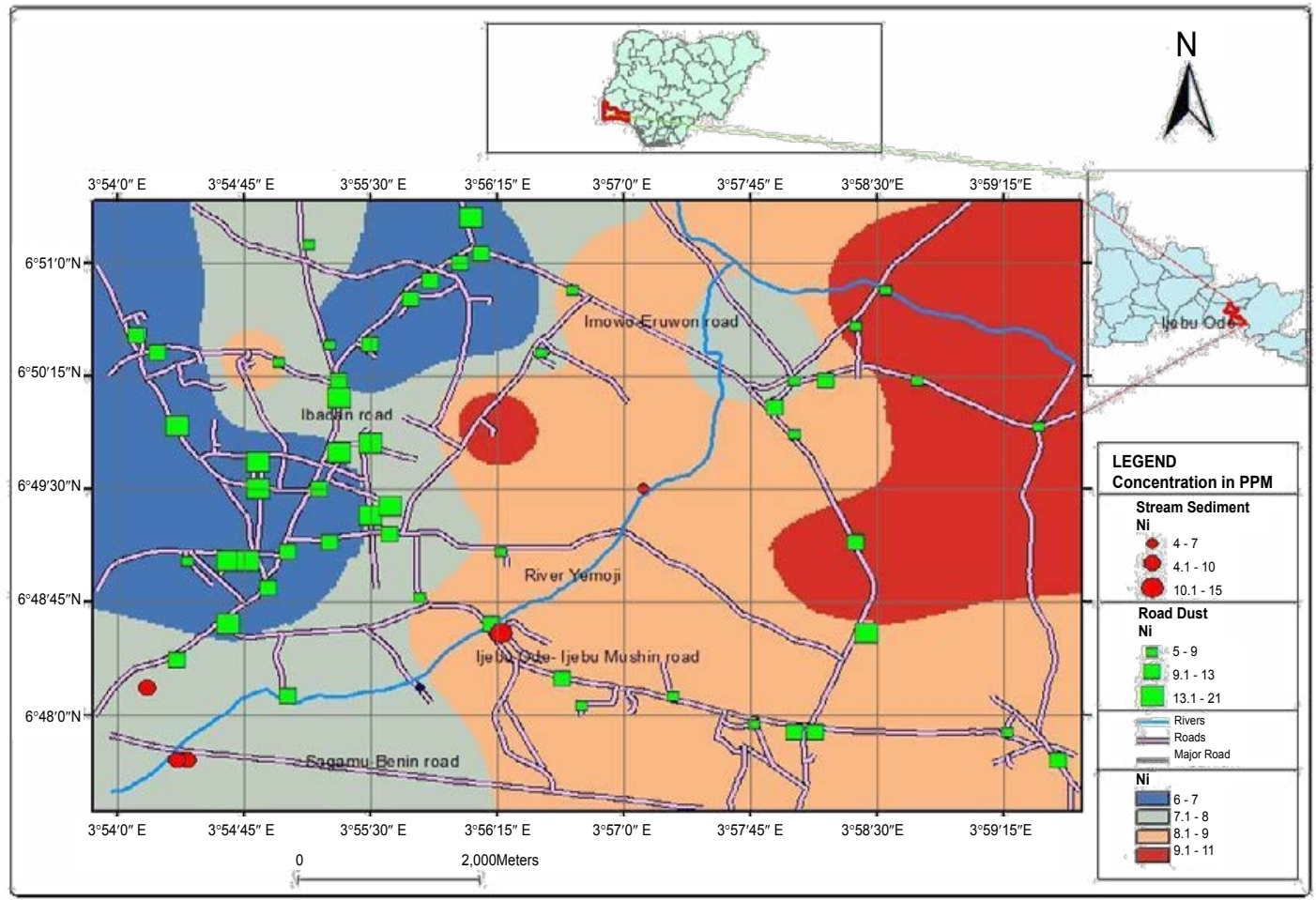

Figure 7: Spatial distribution of $\mathrm{Ni}$ in ljebu-Ode

materials, leaching or physico-chemical depositional characteristics [14].

The correlation analysis revealed varying levels of correlation between the metals in the soil, road dust and stream sediments (Tables 2-4). For the soil samples, $\mathrm{Pb}$ displayed very low correlation with every other metal evaluated an indication of a different pathway for $\mathrm{Pb}$ introduction in the soil of the study area. However, $\mathrm{Zn}$ have high correlation with $\mathrm{As}, \mathrm{Cr}$ and $\mathrm{Cu}$ with correlation matrix $>0.5$; an indication of a similar geochemical pathway of their introductions into the soil of the study area (Table 2). For the road dust samples however, $\mathrm{Pb}$ showed very strong correlations with $\mathrm{Cu}, \mathrm{Zn}$ and $\mathrm{Ni}$ 
Citation: Akinade SO, Olisa O (2014) Geochemical Study of Soils, Road Dust and Stream Sediments around ljebu-Ode, Southwestern, Nigeria. J Environ Anal Toxicol 4: 229. doi: 10.4172/2161-0525.1000229

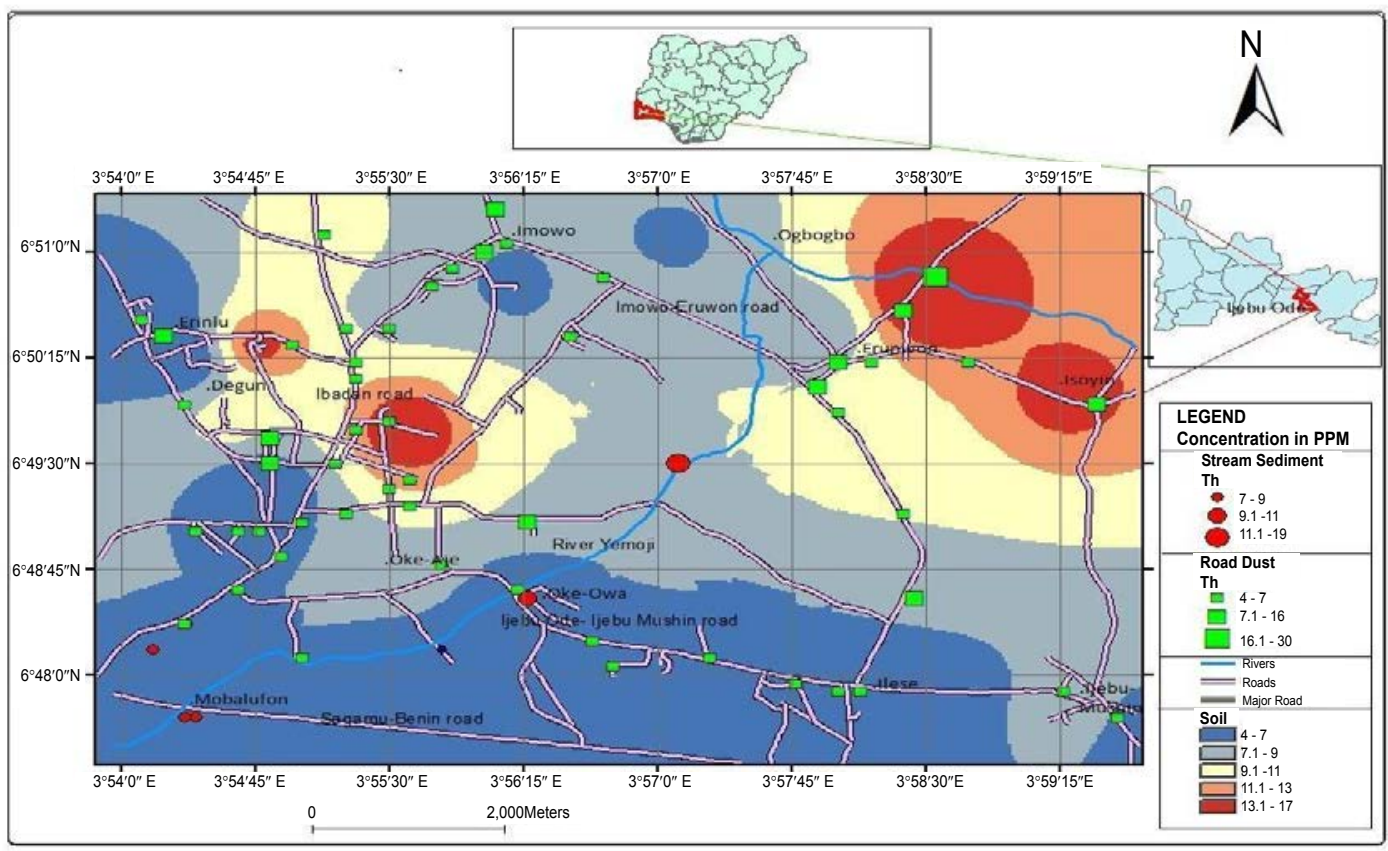

Figure 8: Spatial distribution of Th in ljebu-Ode.

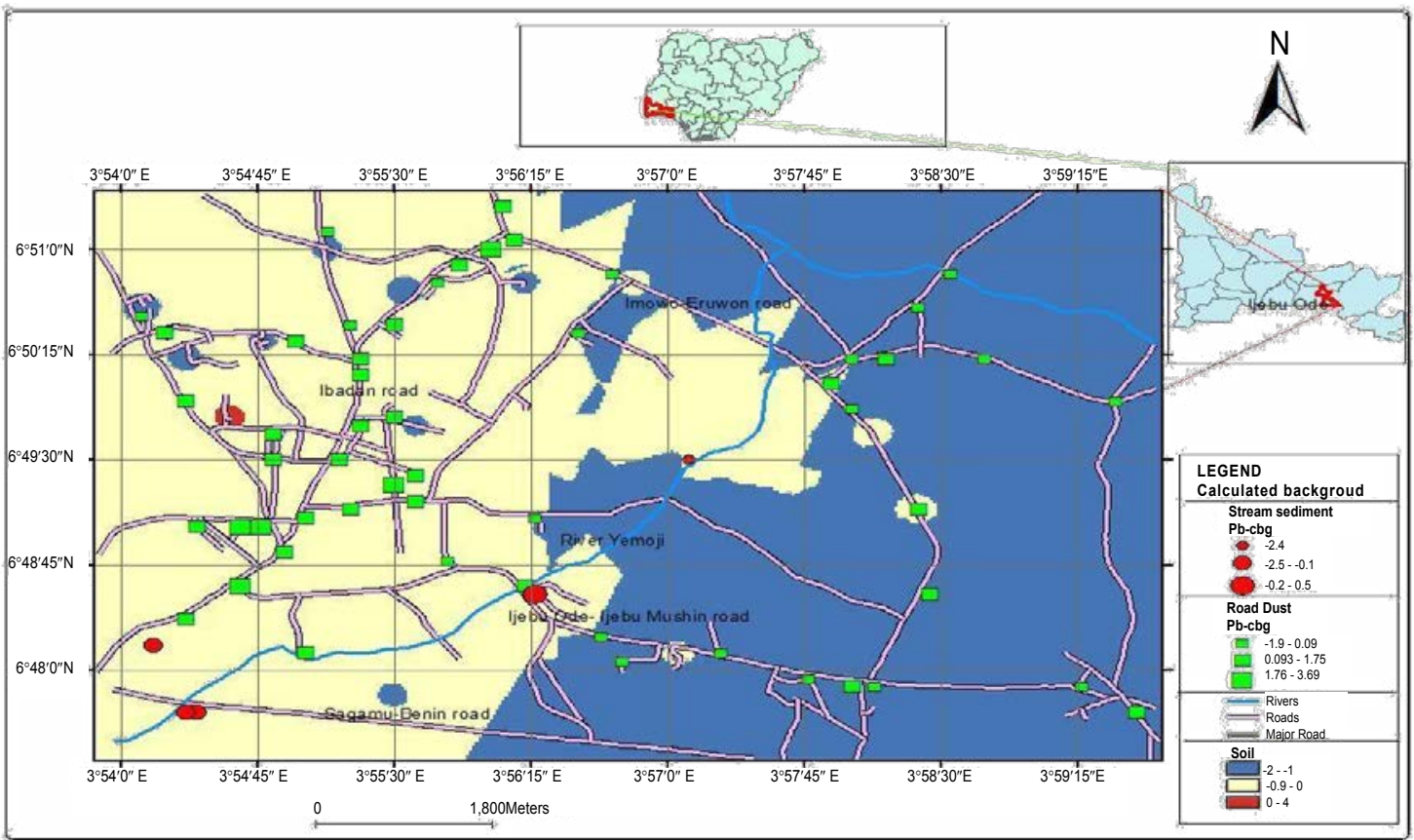

Figure 9: Igeo map of Lead in ljebu-Ode.

with correlation matrix of $>0.5$ and indication that these metals have been introduced into the road dusts from same sources (Table 3 ). The correlation analysis for the sediment results showed that the metals have varying degrees of correlation amongst each other and indication that the drainage sediments showed that the metals in the soils and road dusts samples have found their way into the sediments (Table 4).

\section{R-mode factor analysis}

Factor Analysis involves the reduction of a data set of many variables into one of considerably fewer linear combinations variables that account for an acceptable proportion of the total data variance and which can often be more readily related to recognizable geological 
Citation: Akinade SO, Olisa O (2014) Geochemical Study of Soils, Road Dust and Stream Sediments around ljebu-Ode, Southwestern, Nigeria. J Environ Anal Toxicol 4: 229. doi: 10.4172/2161-0525.1000229

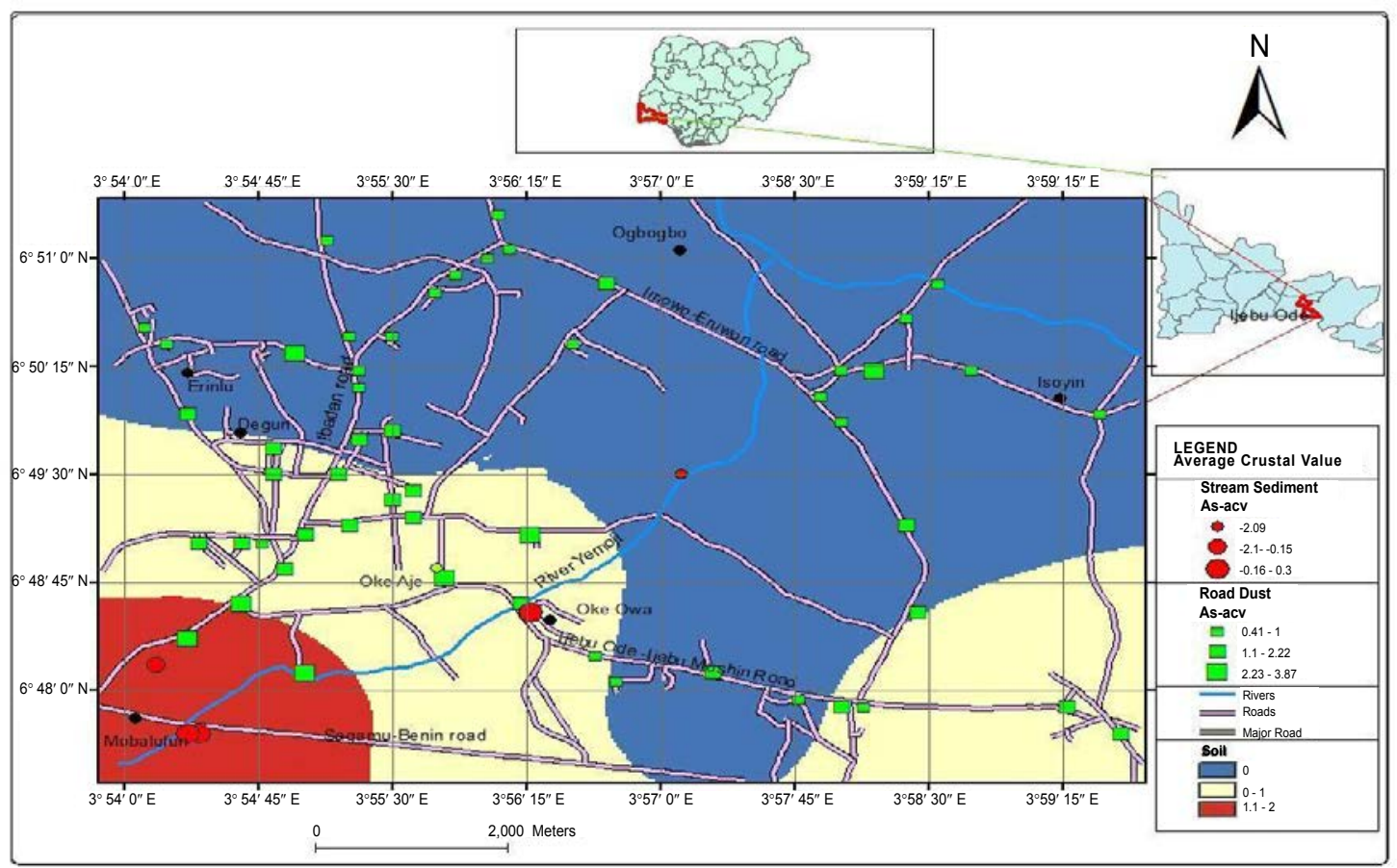

Figure 10: Igeo map of Arsenic in ljebu-Ode.

\begin{tabular}{|c|c|c|c|c|c|c|c|c|c|c|c|c|}
\hline & $\mathbf{P b}$ & $\mathrm{Zn}$ & $\mathrm{Ni}$ & Co & Mn & As & Th & Sr & V & $\mathrm{Cr}$ & $\mathrm{Ba}$ & $\mathrm{Cu}$ \\
\hline $\mathrm{Pb}$ & 1 & & & & & & & & & & & \\
\hline $\mathrm{Zn}$ & -0 & 1 & & & & & & & & & & \\
\hline $\mathrm{Ni}$ & -0.1 & -0.03 & 1 & & & & & & & & & \\
\hline Co & -0.1 & -0.18 & 0.32 & 1 & & & & & & & & \\
\hline$M n$ & -0.2 & -0.23 & -0.1 & $.67^{* *}$ & 1 & & & & & & & \\
\hline As & 0.02 & $.67^{* *}$ & -0 & $-.49^{* *}$ & $-.59^{* *}$ & 1 & & & & & & \\
\hline Th & 0.07 & -0.26 & $.57^{*}$ & $.41^{*}$ & 0.09 & -0.38 & 1 & & & & & \\
\hline $\mathrm{Sr}$ & -0.1 & $.54^{\star *}$ & 0.16 & -0.09 & -0.14 & $.47^{\star *}$ & -0.29 & 1 & & & & \\
\hline $\mathbf{v}$ & 0.04 & 0.09 & $.78^{*}$ & 0.22 & -0.22 & 0.16 & $.74^{* *}$ & 0.19 & 1 & & & \\
\hline $\mathrm{Cr}$ & -0 & $.53^{* *}$ & 0.34 & $-.37^{*}$ & $-.59^{* *}$ & $.76^{* *}$ & -0.12 & $.52^{\star \star}$ & $.47^{\star *}$ & 1 & & \\
\hline $\mathrm{Ba}$ & -0.2 & $.49^{* *}$ & 0.17 & $.63^{* *}$ & $.39^{*}$ & 0.056 & -0.05 & $.40^{*}$ & 0.06 & 0.04 & 1 & \\
\hline $\mathrm{Cu}$ & 0.15 & $.59^{* *}$ & 0.27 & 0.255 & 0 & 0.16 & 0.13 & $.38^{*}$ & $.40^{*}$ & $.44^{*}$ & $.49^{*}$ & 1 \\
\hline
\end{tabular}

${ }^{* *}$ Correlation is significant at the 0.01 level (2-tailed) ${ }^{*}$ Correlation is significant at the 0.05 level (2-tailed)

Table 2: Correlation matrix for selected metals in the soil samples.

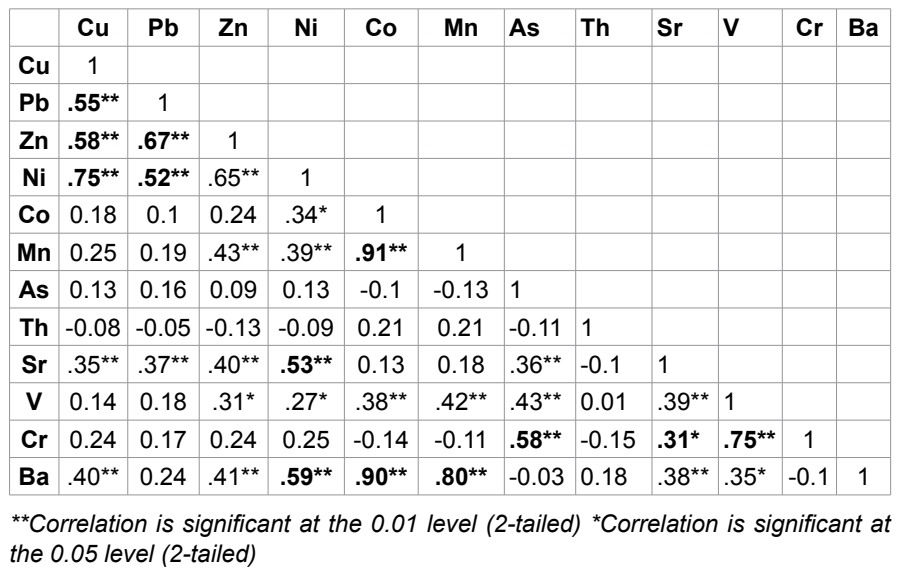

Table 3: Correlation matrix for selected metals in the soil samples.

\begin{tabular}{|c|c|c|c|c|c|c|c|c|c|c|c|c|}
\hline & $\mathrm{Cu}$ & $\mathbf{P b}$ & $\mathrm{Ni}$ & Co & $M n$ & As & $Z n$ & Th & $\mathrm{Sr}$ & V & $\mathrm{Cr}$ & $\mathrm{Ba}$ \\
\hline $\mathrm{Cu}$ & 1 & & & & & & & & & & & \\
\hline $\mathbf{P b}$ & 0.8 & 1 & & & & & & & & & & \\
\hline $\mathbf{N i}$ & 0.86 & $.95^{\star}$ & 1 & & & & & & & & & \\
\hline Co & 0.654 & 0.77 & 0.6 & 1 & & & & & & & & \\
\hline Mn & $.90^{*}$ & 0.86 & 0.86 & 0.82 & 1 & & & & & & & \\
\hline As & 0.762 & 0.32 & 0.56 & 0.1 & 0.6 & 1 & & & & & & \\
\hline $\mathrm{Zn}$ & $.937^{*}$ & 0.67 & 0.84 & 0.36 & 0.76 & $.89^{*}$ & 1 & & & & & \\
\hline Th & $-.89^{*}$ & -0.5 & -0.55 & -0.7 & -0.8 & -0.7 & -0.8 & 1 & & & & \\
\hline $\mathrm{Sr}$ & 0.751 & 0.73 & 0.64 & $.93^{*}$ & $.93^{*}$ & 0.38 & 0.52 & -0.75 & 1 & & & \\
\hline $\mathbf{V}$ & $.91^{*}$ & 0.84 & $.93^{*}$ & 0.6 & $.95^{*}$ & 0.74 & $.89^{*}$ & -0.68 & 0.76 & 1 & & \\
\hline $\mathrm{Cr}$ & 0.91 & $.93^{*}$ & $.97^{\star *}$ & 0.7 & $.95^{\star}$ & 0.62 & 0.85 & -0.66 & 0.78 & $.98^{\star \star}$ & 1 & \\
\hline Ba & $.939 *$ & 0.64 & 0.66 & 0.62 & 0.79 & 0.67 & 0.82 & $-.98^{* *}$ & 0.72 & 0.72 & 0.7 & 1 \\
\hline
\end{tabular}

${ }^{*}$ Correlation is significant at the 0.05 level (2-tailed). ${ }^{* *}$ Correlation is significant at the 0.01 level (2-tailed)

Table 4: Correlation matrix for selected metals in stream sediments.

\begin{tabular}{|c|c|c|c|c|c|}
\hline & \multicolumn{4}{|c|}{ Component } & \\
\hline Elements & $\mathbf{1}$ & $\mathbf{2}$ & $\mathbf{3}$ & $\mathbf{4}$ & Communality \\
\hline $\mathbf{P b}$ & -0.115 & -0.403 & -0.035 & $\mathbf{0 . 7 4 8}$ & 0.736 \\
\hline $\mathbf{Z n}$ & -0.567 & $\mathbf{0 . 6 1 6}$ & $\mathbf{- 0 . 1 7 9}$ & 0.203 & 0.774 \\
\hline $\mathbf{N i}$ & $\mathbf{0 . 6 2 5}$ & 0.561 & 0.17 & -0.017 & 0.735 \\
\hline $\mathbf{C o}$ & $\mathbf{0 . 7 8 7}$ & 0.217 & -0.545 & -0.023 & 0.965 \\
\hline $\mathbf{M n}$ & $\mathbf{0 . 6 1 4}$ & 0.182 & -0.662 & -0.206 & 0.891 \\
\hline $\mathbf{A s}$ & -0.791 & 0.265 & $\mathbf{0 . 3 1 9}$ & -0.118 & 0.812 \\
\hline $\mathbf{S r}$ & $\mathbf{0 . 8 9 1}$ & -0.075 & 0.151 & 0.202 & 0.862 \\
\hline $\mathbf{V}$ & -0.284 & $\mathbf{0 . 7 8 4}$ & 0.257 & -0.085 & 0.769 \\
\hline $\mathbf{C r}$ & $\mathbf{0 . 7 2 5}$ & 0.417 & 0.451 & 0.168 & 0.931 \\
\hline $\mathbf{B a}$ & -0.679 & $\mathbf{0 . 4 6 9}$ & 0.357 & -0.037 & 0.809 \\
\hline $\mathbf{C u}$ & -0.063 & $\mathbf{0 . 7 0 2}$ & -0.584 & -0.077 & 0.845 \\
\hline Cu & -0.161 & 0.491 & -0.434 & $\mathbf{0 . 5 8 8}$ & 0.801 \\
\hline Percentage of variance (\%) & 37.68 & 21 & 14.69 & 8.096 & \\
\hline Cumulative percentage (\%) & 37.68 & 58.69 & 73.37 & 81.47 & \\
\hline
\end{tabular}

Table 5: The result of principal component analysis for Soils in the study area. 
Citation: Akinade SO, Olisa O (2014) Geochemical Study of Soils, Road Dust and Stream Sediments around ljebu-Ode, Southwestern, Nigeria. J Environ Anal Toxicol 4: 229. doi: 10.4172/2161-0525.1000229

Page 8 of 10

\begin{tabular}{|c|c|c|c|c|c|}
\hline & \multicolumn{4}{|c|}{ Component } & \\
\hline Elements & $\mathbf{1}$ & $\mathbf{2}$ & $\mathbf{3}$ & $\mathbf{4}$ & Communality \\
\hline $\mathbf{P b}$ & $\mathbf{0 . 6 6}$ & -0.223 & -0.501 & 0.296 & 0.824 \\
\hline $\mathbf{Z n}$ & $\mathbf{0 . 4 2 9}$ & -0.203 & -0.539 & 0.031 & 0.517 \\
\hline $\mathbf{N i}$ & $\mathbf{0 . 6 5 7}$ & -0.11 & -0.47 & -0.222 & 0.714 \\
\hline $\mathbf{C o}$ & $\mathbf{0 . 7 7 7}$ & -0.192 & -0.413 & 0.205 & 0.852 \\
\hline $\mathbf{M n}$ & 0.609 & $\mathbf{0 . 7 0 8}$ & 0.154 & -0.155 & 0.92 \\
\hline $\mathbf{A s}$ & 0.617 & $\mathbf{0 . 6 9 6}$ & 0.057 & -0.196 & 0.907 \\
\hline $\mathbf{T h}$ & 0.315 & -0.773 & $\mathbf{0 . 4 0 2}$ & 0.124 & 0.873 \\
\hline $\mathbf{S r}$ & 0.006 & 0.524 & 0.294 & $\mathbf{0 . 6 9}$ & 0.837 \\
\hline $\mathbf{V}$ & $\mathbf{0 . 5 0 4}$ & -0.373 & -0.004 & 0.007 & 0.393 \\
\hline $\mathbf{C r}$ & -0.069 & $\mathbf{0 . 6 7}$ & 0.058 & 0.665 & 0.899 \\
\hline $\mathbf{B a}$ & $\mathbf{0 . 5 9 2}$ & 0.36 & 0.5 & -0.3 & 0.82 \\
\hline $\mathbf{C u}$ & $\mathbf{0 . 7 6 5}$ & 0.55 & -0.029 & -0.05 & 0.891 \\
\hline Initial Eigen values & $\mathbf{4 . 4 6 6}$ & 3.726 & 2.262 & 1.473 & \\
\hline Percentage of variance (\%) & 29.77 & 24.84 & 15.08 & 9.823 & \\
\hline Cumulative percentage (\%) & 29.77 & 54.61 & 69.69 & 79.51 & \\
\hline
\end{tabular}

Table 6: The result principal component analysis for Road Dust in the study area.

\begin{tabular}{|c|c|c|c|c|c|c|}
\hline & \multicolumn{2}{|c|}{ Soil } & \multicolumn{2}{c|}{ Road dust } & \multicolumn{2}{c|}{ Stream sediment } \\
\hline Element & MR range & Igeo range & MR range & $\begin{array}{l}\text { Igeo } \\
\text { range }\end{array}$ & $\begin{array}{l}\text { MR } \\
\text { range }\end{array}$ & Igeo range \\
\hline $\mathrm{Pb}$ & $0-30$ & -1 to 4 & $1-19$ & -1 to 4 & $0-1$ & -3 to 1 \\
\hline $\mathrm{Zn}$ & $0-3$ & -3 to 0 & $1-5$ & -3 to 2 & $0-3$ & -2 to 1 \\
\hline $\mathrm{Cu}$ & $0-1$ & -2 t0 -1 & $1-6$ & $0-2$ & $0-1$ & -3 to 1 \\
\hline $\mathrm{As}$ & $6-\mathrm{Jan}$ & -1 to 2 & $2-11$ & 0 to 3 & $6-\mathrm{Jan}$ & -1 to 2 \\
\hline $\mathrm{Cr}$ & $0-1$ & -2 to 2 & $1-6$ & -2 to 1 & $0-2$ & -2 to 0 \\
\hline $\mathrm{Ni}$ & $2-\mathrm{Jan}$ & -1 to 0 & $1-3$ & -1 to 0 & $1-2$ & -2 to 0 \\
\hline
\end{tabular}

Table 7: Calculated MR and Igeo for selected elements in ljebu-Ode.

and environmental processes than the input variables themselves. The results were subjected to R-mode factor analysis following the steps described by Davis [15]. The results are presented in Tables 5 and 6.

The Principal Component Analysis (PCA) for soil revealed a 4 factor model; with factor 1 made up of $\mathrm{Ni}, \mathrm{Co}, \mathrm{Mn}$, Th and $\mathrm{V}$ and Factor 2 consisting of $\mathrm{Zn}, \mathrm{Sr}, \mathrm{Cr}$ and $\mathrm{Ba}$ accounting for $37.684 \%$ and $21 \%$ of the variance respectively. The grouping of these metals together revealed that their occurrence in the soils of the study area is dependent more on geologic processes rather than anthropogenic.

Factor 3 consists of just as while factor 4 consist $\mathrm{Pb}$ and $\mathrm{Cu}$ accounting for $14.685 \%$ and $8.1 \%$ of the variance respectively for the soil samples. These two groups of metals ( $\mathrm{As}, \mathrm{Pb}$ and $\mathrm{Cu}$ ) have been contributed to the soil through anthropogenic activities such as fossil fuel combustion and incineration at waste dumps.

Similarly a 4-component model was also derived for the analysis of the results for the road dusts samples. Factor 1 consist $\mathrm{Pb}, \mathrm{Zn}, \mathrm{Ni}$, $\mathrm{Co}, \mathrm{V}, \mathrm{Ba}, \mathrm{Cu}$ and it accounts for $29.8 \%$ of the variance, while Factor 2 consist of $\mathrm{Mn}$, As and $\mathrm{Cr}$ accounting for $24.8 \%$ of the variance. These metals would have been contributed into the environment by aerosols deposits from vehicular emissions, wear and tear of brake pads and lining of clutch plates as well as wear and tear of aged vehicle parts; materials made from alloying of these various metals in diverse proportions and quantities.

Factor 3 consists of Th, while Factor 4 consists of Sr accounting for $15.1 \%$ and $9.83 \%$ of the variance. These groups have been contributed by mainly geologic processes.

\section{Quality of environmental media}

The quality of the environmental media was assessed using the metal ratio, Index of geo-accumulation (Igeo), Pollution Load Index (PLI), Contamination Factor (CF) and Contamination Degree (CDeg).

\section{Metal Ratio (MR)}

The metal ratio is a pollution quantification index obtained by comparing the observed heavy metal concentration with the background concentration. This is usually expressed as

$$
\mathrm{MR}=\mathrm{Cn} / \mathrm{Bn}
$$

Where $\mathrm{MR}=$ Metal ratio; $\mathrm{Cn}=$ Measured concentration and $\mathrm{Bn}$ $=$ Background concentration

The MR values are interpreted as follows:

$\mathrm{MR}<1$ means no contamination

$1 \leq \mathrm{MR}<3$ means moderate contamination;

$3 \leq \mathrm{MR} \leq 6$ indicates considerable contamination and

MR $>6$ indicates very high contamination.

The calculated MR for the environmental media studied is presented in Table 7. Metals with significance metal ratios in the study area include $\mathrm{Pb}$ and $\mathrm{Zn}, \mathrm{Cr}$ and $\mathrm{Mn}$. Areas with elevated $\mathrm{MR}$ for soils include areas with waste disposal sites, auto-mechanic workshops and metal works. All activities which would have contributed to elevated metal load in the soils of the city. A MR of 30 was calculated for $\mathrm{Pb}$ for a soil sample obtained from a waste dump site in the city.

Areas of elevated metal ratio for road dust with high metal ratio of $\mathrm{Pb}, \mathrm{Zn}$ and $\mathrm{Cu}$ are the areas with high traffic density and dense population while in the stream sediments, $\mathrm{Pb}, \mathrm{Zn}$, $\mathrm{As}$ and $\mathrm{Cu}$ has high metal ratio due to in sediments draining agricultural zones where wash-off from vegetable farms upstream and waste water from poultry farms are received into the river channel.

\section{Geo-accumulation index (Igeo)}

Geo-accumulation index (Igeo) was introduced by Muller [16] and has been used since the late 1960s, widely in quantification of heavy metal pollution studies. The index of geo-accumulation (Igeo) is used in the assessment of contamination by comparing the levels of heavy metal obtained to a background levels originally used with bottom sediments [16]. It can also be applied to the assessment of road dust contamination [17-19]. Geo-accumulation index is expressed as follows:

$$
\text { Igeo }=\log 2 \mathrm{Cn} / 1.5 \mathrm{Bn}
$$

Where $\mathrm{Cn}$ is the concentration of element in sample and $\mathrm{Bn}$ is the background value and the constant 1.5 allowed for analyzing natural fluctuations in the content of a given substance.

The calculated Igeo are presented in Table 7. The calculated Igeo revealed that $\mathrm{Pb}, \mathrm{Zn}, \mathrm{Cu} \mathrm{As}$ and $\mathrm{Cr}$ vary from practically uncontaminated in some areas to moderately contaminated. However, the Soils and road dusts showed greater level of contamination when compared to the sediment.

Igeo maps for $\mathrm{Pb}$ and $\mathrm{As}$ were plotted in order to ascertain the specific location with the extreme Igeo values owing to the very toxic natures of these two metals (Figures 9 and 10). 
Citation: Akinade SO, Olisa O (2014) Geochemical Study of Soils, Road Dust and Stream Sediments around ljebu-Ode, Southwestern, Nigeria. J Environ Anal Toxicol 4: 229. doi: 10.4172/2161-0525.1000229

Page 9 of 10

\section{Contamination Factor (CF) and Contamination Degree (CDeg)}

$\mathrm{CF}$ and CDeg were also evaluated to ascertain the level of deterioration or otherwise in the quality of the environmental media. $\mathrm{CF}$ is expressed as:

\section{$\mathrm{CF}=$ Metal content in the sediment / Background value of metal}

CDeg is expressed as: $\mathbf{C D e g}=\mathbf{C F}($ selected metal $) / \Sigma \mathrm{CF}^{\star} \mathbf{1 0 0}$

CF indicates the individual impact of each metal on the sample while the CDeg is sum of all the elements in the sample.

The calculated CF and CDeg in the soils, road dust and sediments were interpreted using the classification proposed by Hakanson [20] (Table 8).

The calculated CF (Table 9) revealed that $\mathrm{Pb}, \mathrm{As}, \mathrm{Th}, \mathrm{Mn}$, and $\mathrm{V}$ revealed moderate contamination in soils while $\mathrm{Pb}, \mathrm{As}, \mathrm{Cu}$ and $\mathrm{Zn}$ show moderate contamination in road dust. In the stream sediments, As showed considerable contamination with $\mathrm{Zn}$ and $\mathrm{Th}$ and showed moderate contamination.

The calculated and CDeg (Table 9) indicated that $\mathrm{Pb}, \mathrm{Zn}, \mathrm{As}$ and $\mathrm{V}$ are the most significant pollutants in the study area with $\mathrm{Pb}$ and $\mathrm{Zn}$ showing the highest contamination degrees.

\section{Pollution Load Index (PLI)}

The PLI was calculated using the formula proposed by Thomilson et al. [21]. This is given as:

$$
\text { PLI }=[(\mathrm{CF} 1)(\mathrm{CF} 2)(\mathrm{CF} 3) \ldots \ldots . .(\mathrm{CFn})]^{1 / \mathrm{n}}
$$

Where $\mathrm{n}$ is the number of selected metals for the assessment of PLI and $\mathrm{CF}$ is the Contamination Factor calculated as described in equation (4).

The PLI provides simple but comparative means for assessing a site/location's sample quality, where values of:

\section{PLI $<1$ denote perfection;}

PLI $=1$ present that only baseline levels of pollutants are present and

PLI $>1$ would indicate deterioration in quality of environmental at the site/location.

The PLI $>1.0$ indicates that metal concentrations are above the permissible level; PLI $<1.0$ indicates that average levels of metals are below the selected standards but does not necessarily indicate that there is no anthropogenic source or other enrichment over background [22].

The evaluated PLI in the soil samples from Ijebu-Ode ranges from 0.52 to 1.20 with about $87 \%$ of the soils having PLI $<1.0$ an indication that the pollution level of some of the areas are within baseline levels but with some location indicating grave deterioration in the quality of the soils. These are confined to samples within the city center where there is very dense population and very in-efficient sanitary and poor waste management services.

However for the road dusts, calculated PLI ranges from 0.54 to 2.02 with over $57 \%$ of the road dusts having PLI $>1.0$. The major roads have all their PLI values $>1.0$ and indication that volume of vehicular activities have a negative impact on the quality of the road dusts as areas with dust of low PLI are found on the minor roads in the study

\begin{tabular}{|l|l|l|l|}
\hline Contamination Factor (CF) & \multicolumn{2}{|l|}{ Contamination } & Degree (CDeg) \\
\hline Class & Indication & Class & Indication \\
\hline $\mathrm{CF}<1$ & Low Contamination & $\mathrm{Cdeg}<8$ & Low degree of contamination \\
\hline $1<\mathrm{CF}<3$ & $\begin{array}{l}\text { Moderately } \\
\text { contaminated }\end{array}$ & $8 \leq \mathrm{Cdeg}<16$ & $\begin{array}{l}\text { Moderate degree of contamina- } \\
\text { tion }\end{array}$ \\
\hline $3<\mathrm{CF}<6$ & $\begin{array}{l}\text { Considerable } \\
\text { contamination }\end{array}$ & $16 \leq \mathrm{Cdeg}<32$ & $\begin{array}{l}\text { Considerable degree of } \\
\text { contamination }\end{array}$ \\
\hline $6<\mathrm{CF}$ & $\begin{array}{l}\text { Very high } \\
\text { contamination }\end{array}$ & $32 \leq \mathrm{Cdeg}$ & $\begin{array}{l}\text { Very High degree of contamina- } \\
\text { tion }\end{array}$ \\
\hline
\end{tabular}

Table 8: CF and CDeg Classification Hakanson 1980.

\begin{tabular}{|c|c|c|c|c|c|c|}
\hline & \multicolumn{3}{|c|}{ Contamination Factor (CF) } & \multicolumn{3}{c|}{ Contamination Degree (CDeg) } \\
\hline & & Road & & & Road & \\
\hline Metals & Soils & Dusts & Sediments & Soil & Dusts & Sediments \\
\hline $\mathbf{C u}$ & 0.73 & 2.36 & 1.03 & 4.5 & 11.3 & 5 \\
\hline $\mathbf{P b}$ & 1.77 & 3.16 & 1.19 & 10.9 & 15.1 & 5.8 \\
\hline $\mathbf{Z n}$ & 0.49 & 1.98 & 1.69 & 3 & 9.5 & 8.2 \\
\hline $\mathbf{N i}$ & 1.12 & 1.41 & 0.92 & 6.9 & 6.7 & 4.5 \\
\hline $\mathbf{C o}$ & 0.29 & 0.29 & 1.2 & 1.8 & 1.4 & 5.8 \\
\hline $\mathbf{M n}$ & 1.37 & 0.95 & 0.93 & 8.5 & 4.5 & 4.5 \\
\hline $\mathbf{A s}$ & 1.63 & 2.33 & 3.67 & 10.1 & 11.1 & 17.9 \\
\hline $\mathbf{T h}$ & 1.31 & 0.99 & 1.35 & 8.1 & 4.7 & 6.6 \\
\hline $\mathbf{S r}$ & 0.68 & 1.11 & 1.25 & 4.2 & 5.3 & 6.1 \\
\hline $\mathbf{V}$ & 1.15 & 0.88 & 1.22 & 7.1 & 4.2 & 5.9 \\
\hline $\mathbf{L a}$ & 1.15 & 1.02 & 1.31 & 7.1 & 4.9 & 6.4 \\
\hline $\mathbf{C r}$ & 0.56 & 1.07 & 1.08 & 3.5 & 5.1 & 5.3 \\
\hline $\mathbf{B a}$ & 0.46 & 1.09 & 0.88 & 2.8 & 5.2 & 4.3 \\
\hline
\end{tabular}

Table 9: Results of contamination factor and contamination degree.

area. For the sediments, the PLI ranges from 0.5 to 1.8 with the stream sediments samples obtained away from zones draining the city center have greater PLI values.

\section{Conclusions}

Metal concentration and distribution in environmental media of Ijebu-Ode using different methods of Pollution assessment revealed different levels of contamination in the media examined. The road dusts were shown to have been more impacted followed by the soil and the sediments. Areas identified to be heavily impacted are those associated with huge vehicular activities, zones around waste dumps and agricultural areas.

Increased urbanization had resulted in increase in level of pollution of the environmental media. There is a risk that if the metal loads continue to rise as it is currently the case, there may be further impact on the groundwater system in the light of the silty-sandy nature of the soil cover which will aid rapid infiltrations. To reduce the effect of these, there is a greater need to increase environmental awareness and to develop ways to reduce environmental pollution as well as taking necessary steps to remediate sites with excessive metal loads as revealed in this study.

\section{References}

1. Sutherland RA (2000) Bed sediment-associated trace metals in an urban stream,Oahu, Hawaii. Environmental Geology 39: 611-637.

2. Reichman SM (2002) The Responses of Plants to Metal Toxicity: A review focusing on Copper, Manganese and Zinc. Australian Minerals \& Energy Environment Foundation.

3. Adelekan BA, Abegunde KD (2011) Heavy metals contamination of soil and groundwater at an automobile mechanic villages in Ibadan, Nigeria International Journal of the Physical Sciences 6: 1045-1058. 
Citation: Akinade SO, Olisa O (2014) Geochemical Study of Soils, Road Dust and Stream Sediments around ljebu-Ode, Southwestern, Nigeria. J Environ Anal Toxicol 4: 229. doi: 10.4172/2161-0525.1000229

4. Thornton I, Webb JS (1979) Geochemistry and health in the United Kingdom. Philos Trans R Soc Lond B Biol Sci 288: 151-168.

5. Plant J, Moore PJ (1979) Regional geochemical mapping and interpretation in Britain. Philos Trans R Soc Lond B Biol Sci 288: 95-112.

6. Lombart M, de Bruin D, Elsenbroek JH (1999) High-density regional geochemical mapping of soils and stream sediments in South Africa. Journal of Geochemical Exploration 66: 145-149.

7. Thuy HTT, Tobschall HJ, An PV (2000) Trace elemental distributions in aquatic sediments of Danang-Hoian area, Vietnam. Environmental Geology 39: 733740

8. Assah VA, Abimbola AF, Suh CE (2006) Heavy metal concentration and distribution in surface soils of the Bassa Industrial Zone1, Douala, Cameroon. The Arabian Journal for Science and Engineering 31: 147-158.

9. Abimbola AF, Kehinde-Phillips OO, Olatunji AS (2007) The Sagamu cement factory, SW Nigeria: is the dust generated a potential health hazard? Environ Geochem Health 29: 163-167.

10. Olatunji AS, Abimbola AF, Afolabi OO (2009) Geochemical assessment of Industrial activities on the quality of sediments and soils within the LSPDC Industrial Estate, Odogunyan, Lagos. Nigeria. Global Journal of Environmental research 3: 252-257.

11. Jones HA, Hockey RD (1964) Geology of part of southwestern Nigeria. Bulletin Geology Survey of Nigeria No.31.

12. Omatsola ME, Adegoke OS (1980) Tectonic evolution of the Dahomey basin and its implication on the opening of the north and south Atlantic block. 26th international geology 268
13. Agagu OK (1985) A Geological guide to bituminous sediments in southwestern Nigeria. Unpublished report, Department of Geology, University of Ibadan 18.

14. Kronberg BI, Fyfe WS, Leonardos OH, Santos AM (1979) The Chemistry of some Brazillian Soils. Chem. Geol 24: 211-229.

15. Davis JC (1986) Statistics and data analysis in Geology. New York: Wiley 647.

16. Muller G (1969) Index of Geoaccumulation in sediments of the Rhine River Geo Journal 2: 108-118.

17. Lu X, Wang L, Lei K, Huang J, Zhai Y (2009) Contamination assessment of copper, lead, zinc, manganese and nickel in street dust of Baoji, NW China. J Hazard Mater 161: 1058-1062.

18. Lu X, Wang L, Li LY, Lei K, Huang L, et al. (2010) Multivariate statistical analysis of heavy metals in street dust of Baoji, NW China. J Hazard Mater 173: 744749 .

19. Srinivasa Gowd S, Ramakrishna Reddy M, Govil PK (2010) Assessment of heavy metal contamination in soils at Jajmau (Kanpur) and Unnao industria areas of the Ganga Plain, Uttar Pradesh, India. J Hazard Mater 174: 113-121.

20. Hakanson $L$ (1980) An ecological risk index for aquatic pollution control. A sedimentological approach. Water Resources 14: 975-1001.

21. Tomlinson DL, Wilson JG, Harris CG, Jeffney DW (1980) Problems in the assessment of heavy metal levels in estuaries and the formation of a pollution index. Helgol Meeresunters 33: 566-575.

22. Nimick DA, Moore JM (1991) Prediction of water soluble metal concentrations in fluvially deposited tailing sediments, Upper Clark Fork Valley, Montana, U.S.A. Applied Geochemistry 6: 635-646. 